УДК 378:5:579.2

DOI 10.11603/me.2414-5998.2021.2.12409

Н. Я. Кравець

ORCID https://orcid.org/0000-0002-7593-1753

ResearcherID B-4088-2016

Scopus Author ID 57215490836

С. І. Климнюк

ORCID https://orcid.org/0000-0002-1308-3250

ResearcherID Q-5460-2016

Scopus Author ID 6506607549

Тернопільський національний медичний університет імені І. Я. Горбачевського МОЗ Украӥни

\title{
ОНОВЛЕННЯ ЗМІСТУ НАВЧАЛЬНОЇ ДИСЦИПЛІНИ «МІКРОБІОЛОГІЯ, ВІРУСОЛОГІЯ І ІМУНОЛОГІЯ» НА ОСНОВІ НАУКОВИХ ДОСЯГНЕНЬ І СУЧАСНИХ ПРАКТИК
}

\author{
N. Ya. Kravets, S. I. Klymnyuk \\ I. Horbachevsky Ternopil National Medical University \\ RENEWAL OF THE CONTENT OF THE COURSE "MICROBIOLOGY, \\ VIROLOGY AND IMMUNOLOGY” ON THE BASIS OF SCIENTIFIC \\ ACHIEVEMENTS AND MODERN PRACTICES
}

\begin{abstract}
Анотація. У статті розглянуто зміст навчальної дисципліни «Мікробіологія, вірусологія і імунологія», що належить до циклу вибіркових дисциплін професійної підготовки освітньо-наукової програми підготовки докторів філософії (здобувачів третього рівня вищої освіти) за спеціальністю 091 «Біологія» у галузі знань 09 «Біологія». Сучасне суспільство сьогодні потребує конкурентоспроможного науковця та викладача, тож забезпечення високої якості освітньої підготовки доктора філософії $є$ необхідною умовою при підготовці аспіранта. Зміна освітньої парадигми вимагає оновлення змісту згідно з європейськими стандартами.

У статті висвітлено зміст дисципліни «Мікробіологія, вірусологія і імунологія» та зміни, які відбулися у робочій програмі, що пов’язано з розвитком наук мікробіології, вірусології, імунології, оновленням інформації про нові структури інфекційної патології, пов’язаної зі зростанням кількості збудників інфекцій, збільшенням частоти персистентних форм інфекційного процесу, розширенням спектра умовно-патогенних мікроорганізмів з множинною стійкістю до протимікробних засобів, використанням нових методів дослідження матеріалу та ідентифікації мікроорганізмів. Таким чином, зміни в робочій програмі «Мікробіологія, вірусологія і імунологія» для підготовки докторів філософії за спеціальністю 091 «Біологія» спрямовані на поєднання навчальної діяльності з науковим пошуком.
\end{abstract}

Ключові слова: мікробіологія, вірусологія і імунологія; навчальний план; освітньо-наукова програма; робоча програма; доктор філософії.

\begin{abstract}
The article considers the content of the discipline "Microbiology, Virology and Immunology", which belongs to the cycle of elective disciplines of professional training of educational and scientific training programs for doctors of philosophy (third-level higher education) in speciality 091 "Biology" in the branch of knowledge 09 "Biology". Modern society today needs a competitive scientist and teacher, so ensuring high quality educational training of a doctor of philosophy is a necessary condition for the preparation of graduate students. Changing the educational paradigm requires updating the content according to European standards.

The purpose of the work is to cover the updated content of the discipline "Microbiology, Virology and Immunology" on the basis of scientific achievements and modern practices in the field of clinical microbiology, virology and immunology. The article highlights the content of the discipline "Microbiology, Virology and Immunology" and the changes that have occurred in the work program related to the development of microbiology, virology, immunology by updating information on new structures of infectious pathology associated with increasing pathogens, increasing the frequency of persistent forms of the infectious process, expanding the range of opportunistic pathogens with multiple resistance to antimicrobials, using new methods of material research and identification of microorganisms. Thus, changes in the work program "Microbiology, Virology and Immunology" for the preparation of doctors of philosophy in the specialty 091 "Biology" aimed at combining educational activities with scientific research.
\end{abstract}

Key words: microbiology, virology and immunology; educational plan; educational and scientific program; working program; doctor of philosophy.

(c) Н. Я. Кравець, С. І. Климнюк 
Вступ. Початком реформування освітньої системи в Україні є прийняття у 2016 р. Закону «Про вищу освіту». Особливістю реформування освіти в Україні є самостійна розробка вищими навчальними закладами освітніх (освітньо-професійних чи освітньо-наукових) програм [1]. Освітньо-наукова програма підготовки здобувачів третього рівня вищої освіти ступеня доктора філософії в аспірантурі також розробляється самостійно навчальними закладами та затверджується вченою радою вишу для кожної спеціальності відповідно до вимог Порядку підготовки здобувачів вищої освіти ступеня доктора філософії та доктора наук у вищих навчальних закладах (наукових установах), затвердженого Постановою Кабінету Міністрів України від 23.03.2016 р. № 261 [5]. Освітньонаукова програма та навчальний план аспірантури (ад’юнктури) складаються з освітньої та наукової складових. Освітня складова програми направлена на здобуття глибинних знань із спеціальності, а також на набуття універсальних навичок дослідника, що допоможе здобувачеві набути таких компетентностей, які необхідні відповідно до Національної рамки кваліфікації [4].

Сучасне суспільство сьогодні потребує конкурентоспроможного науковця та викладача, тож забезпечення високої якості освітньої підготовки доктора філософії є необхідною умовою при підготовці аспіранта. Зміст вищої освіти обумовлений цілями та потребами суспільства, системою знань, умінь та навичок, професійних, світоглядних і громадянських якостей, що мають бути сформовані в процесі навчання з урахуванням перспектив розвитку суспільства, науки, техніки, технологій, культури та мистецтва [3]. Тож зміна освітньої парадигми вимагає оновлення змісту згідно з європейськими стандартами. Головною умовою ефективності освіти є формування академічної мобільності як необхідної умови розвитку професійної діяльності в середовищі, що постійно змінюється.

В Тернопільському національному університеті ім. І. Я. Горбачевського з 2016 р., згідно з наказом МОН України від 23.12.2016 р. № 1512л, здійснюється підготовка доктора філософії у галузі знань 09 «Біологія» за спеціальністю 091 «Біологія» за очною (денною, вечірньою) та заочною формами навчання [2]. Освітньо-наукова програма поділяється на дві основні частини - нормативні та вибіркові навчальні дисципліни. Перші, у свою чергу, складаються з циклу загальної підготовки та професійної підготовки. Цикл загальної підго- товки наповнений компонентами, які спрямовані на формування системного наукового світогляду, професійної етики, набуття універсальних навичок дослідника, а також здобуття мовних компетентностей, які допоможуть молодому науковцю в опануванні іноземної літератури чи у підготовці до представлення своїх результатів дослідження на наукових форумах, для професійного спілкування тощо [1]. Цикл професійної підготовки поділяється на нормативні дисципліни за обраною аспірантом галуззю знань, які допоможуть йому в опануванні та розумінні теоретичних і практичних проблем за обраною спеціальністю. Вибіркову навчальну дисципліну також розділено на два цикли: загальної та професійної підготовки, які надають можливість аспіранту здійснити поглиблену підготовку зі спеціальності, що визначає характер майбутньої діяльності і сприяє академічній мобільності аспіранта та розвитку його особистих інтересів. Дисциплін, які утворюють цикл як загальної, так і професійної підготовки, повинно бути декілька, що разом з нормативною частиною формують перелік компонент освітньо-наукової програми. Навчальна дисципліна «Мікробіологія, вірусологія і імунологія» належить до циклу вибіркових дисциплін професійної підготовки, яку може обрати не лише здобувач зі спеціалізації «Мікробіологія», а також з інших спеціалізацій для розширення своїх знань з етіології захворювань, викликаних різними патогенними мікроорганізмами, та впливу їх на людину, тож висвітлення актуальної інформації, нових методів дослідження з цієї дисципліни не викликає сумніву.

Мета статті - висвітлення оновленого змісту навчальної дисципліни «Мікробіологія, вірусологія і імунологія» на основі наукових досягнень і сучасних практик у галузі клінічної мікробіології, вірусології та імунології.

Теоретична частина. Навчальна дисципліна «Мікробіологія, вірусологія і імунологія» орієнтована на вивчення основ загальної та медичної мікробіології: морфології, фізіології, біохімії і генетики мікроорганізмів, основних принципів асептики й антисептики, стерилізації та дезінфекції, мікроекології, інфекційної імунології, загальної та спеціальної вірусології, а також включає основні питання біологічних властивостей патогенних мікроорганізмів, взаємодії мікробів з організмом людини, особливостей патогенезу інфекційних захворювань, методів їх діагностики, принципів етіотропного лікування і специфічної профілактики захворювань. 
Підготовка здобувачів третього освітньо-кваліфікаційного рівня має на меті не лише формування знань про загальні закономірності будови, життєдіяльності та розповсюдження мікробів, їх значення як основних представників біосфери, ролі їх у мікробіомі людини, як збудників інфекційних захворювань, контамінантів лікарських препаратів, а також вміння обирати та адекватно застосовувати сучасні мікробіологічні методи при проведенні наукової діяльності та вирішенні актуальних проблем клінічної мікробіології.

Дисципліна викладається на другому курсі аспірантури, коли аспіранти засвоюють знання зі спеціальності для проведення досліджень і розуміння теоретичних та практичних проблем у рамках обраної спеціалізації. Вивчення навчальної дисципліни має бути спрямоване на забезпечення загальних та спеціальних (фахових) компетентностей, мати важливе практичне значення для проведення різного роду мікроскопічних, бактеріологічних, серологіч- них досліджень, а також в умовах лабораторії відтворювати експериментальні моделі патологічних процесів для розробки діагностичних і лікувальних засобів.

Динамічний розвиток мікробіології, вірусології та імунології в сучасному світі вимагає оновлення не лише матеріалів для лекцій чи практичних занять, але й оновлення змісту освітньої компоненти.

Робоча програма з дисципліни структурована на 25 тем та розділена на три розділи (табл. 1):

- загальна мікробіологія як основа для вивчення життєдіяльності представників царства прокаріотів;

- практична імунологія;

- прикладна мікробіологія та вірусологія.

Основний акцент зроблено на вивченні медичної мікробіології, вірусології та імунології, що $є$ важливим для підготовки фахівця медико-біологічного спрямування, і забезпечує перспективу розвитку молодого науковця в галузі медицини, яка стрімко

Таблиця 1. Зміст навчальної дисципліни

\begin{tabular}{|c|c|c|}
\hline Назва розділу & $\begin{array}{l}\text { Номер } \\
\text { заняття }\end{array}$ & Назва теми \\
\hline \multirow{7}{*}{$\begin{array}{l}\text { Розділ І. Загальна } \\
\text { мікробіологія як } \\
\text { основа для вивчення } \\
\text { життєдіяльності } \\
\text { представників } \\
\text { царства прокаріотів }\end{array}$} & 1 & $\begin{array}{l}\text { Мікробіологія як фундаментальна дисципліна. Етапи формування } \\
\text { мікробіології як науки. Еволюція мікроорганізмів }\end{array}$ \\
\hline & 2 & $\begin{array}{l}\text { Принципи класифікації та номенклатури прокаріотів. Основні таксони. } \\
\text { Структурні особливості клітин прокаріотів. Мікроскопічний метод } \\
\text { діагностики. Методи фарбування бактерій }\end{array}$ \\
\hline & 3 & $\begin{array}{l}\text { Вивчення біохімічних, енергетичних процесів, що відбуваються в } \\
\text { бактеріальній клітині та забезпечують її відтворення та ріст. Особливості } \\
\text { приготування поживних середовищ }\end{array}$ \\
\hline & 4 & $\begin{array}{l}\text { Віруси як неклітинні форми життя. Особливості життєвого циклу. Аналіз } \\
\text { методів, що використовуються для оцінки вірусної репродукції }\end{array}$ \\
\hline & 5 & $\begin{array}{l}\text { Генетичні детермінанти спадковості та мінливості мікроорганізмів. } \\
\text { Генна інженерія. Використання молекулярно-генетичних методів у } \\
\text { мікробіологічній практиці }\end{array}$ \\
\hline & 6 & $\begin{array}{l}\text { Антибактеріальні засоби: хіміотерапевтичні препарати та антибіотики. } \\
\text { Антибіотикорезистентність як провідна проблема сучасної медицини }\end{array}$ \\
\hline & 7 & $\begin{array}{l}\text { Поняття про експериментальну інфекцію. Методологія дослідження } \\
\text { інфікованих лабораторних тварин у мікробіологічній практиці }\end{array}$ \\
\hline \multirow[t]{3}{*}{$\begin{array}{l}\text { Розділ II. Практична } \\
\text { імунологія }\end{array}$} & 8 & $\begin{array}{l}\text { Імунна система організму людини: складові компоненти, основні клітини } \\
\text { імунітету, їх функції. Імунітет. Види імунітету. Використання знань про } \\
\text { антигени та антитіла у практичній діяльності. Теоретичні засади взаємодії } \\
\text { клітин в імунній відповіді }\end{array}$ \\
\hline & 9 & $\begin{array}{l}\text { Значення та роль імунологічних методів діагностики у диференціації } \\
\text { патологічних станів організму. Сучасні імунологічні тести для експрес- } \\
\text { діагностики }\end{array}$ \\
\hline & 10 & $\begin{array}{l}\text { Препарати для проведення активної та пасивної імунізації. Сучасні методи } \\
\text { створення вакцин }\end{array}$ \\
\hline
\end{tabular}


Продовження табл. 1

\begin{tabular}{|c|c|c|}
\hline Назва розділу & $\begin{array}{l}\text { Номер } \\
\text { заняття }\end{array}$ & Назва теми \\
\hline \multirow{15}{*}{$\begin{array}{l}\text { Розділ III. } \\
\text { Прикладна } \\
\text { мікробіологія } \\
\text { та вірусологія }\end{array}$} & 11 & Актуальні сучасні інфекції, викликані пікорновірусами, та їх лабораторна діагностика \\
\hline & 12 & $\begin{array}{l}\text { Грип. Особливості пандемічних та епідемічних спалахів грипозної інфекції в умовах } \\
\text { України. Керовані параміксовірусні інфекції (кір, епідпаротит) }\end{array}$ \\
\hline & 13 & $\begin{array}{l}\text { Регіональні арбовірусні інфекції. Лабораторна діагностика вірусних енцефалітів } \\
\text { та геморагічних лихоманок. Загальна характеристика рабдовірусів, ротавірусів, } \\
\text { коронавірусів, аренавірусів }\end{array}$ \\
\hline & 14 & $\begin{array}{l}\text { ДНК-геномні віруси. Герпес- та аденовіруси. Лабораторна діагностика } \\
\text { персистуючих вірусних інфекцій }\end{array}$ \\
\hline & 15 & $\begin{array}{l}\text { Збудники вірусних гепатитів як актуальна проблема сучасної практичної медицини. } \\
\text { Інформативні та оперативні методи лабораторної діагностики вірусних гепатитів. } \\
\text { Скринінгові обстеження груп ризику }\end{array}$ \\
\hline & 16 & $\begin{array}{l}\text { Вірус імунодефіциту людини та його дія на клітини. ДНК та РНК віруси, що } \\
\text { спричиняють трансформацію клітин. Група вірусних захворювань людини і тварин, } \\
\text { що характеризуються тривалим інкубаційним періодом. Наноби }\end{array}$ \\
\hline & 17 & $\begin{array}{l}\text { Збудники захворювань шкіри, слизових оболонок: Staphylococcus spp., Streptococcus } \\
\text { spp., Pseudomonas spp. Збудники анаеробних інфекцій: правця, газової анаеробної } \\
\text { інфекції. Неклостридіальні бактерії }\end{array}$ \\
\hline & 18 & $\begin{array}{l}\text { Збудники діарейних бактеріальних інфекцій: E. coli, Klebsiella pneumoniae, } \\
\text { Enterobacter spp., Campylobacter jejuni, Helicobacter pylori }\end{array}$ \\
\hline & 19 & $\begin{array}{l}\text { Збудники діарейних бактеріальних інфекцій: Vibrio cholerae, Shigella spp. та } \\
\text { Salmonella spp. }\end{array}$ \\
\hline & 20 & $\begin{array}{l}\text { Патогенні бактерії, що передаються статевим шляхом: Neisseria gonorrhoeae, } \\
\text { Treponema pallidum, Chlamidia spp., Mycoplasma ssp. }\end{array}$ \\
\hline & 21 & $\begin{array}{l}\text { Патогенні бактерії, що передаються повітряно-краплинним шляхом: Neisseria menin- } \\
\text { gitidis, Mycobacterium spp., Corynebacterium diphtheriae, Bordetella pertusis }\end{array}$ \\
\hline & 22 & $\begin{array}{l}\text { Патогенні бактерії, які викликають бактеріємію: Salmonella typhy, Leptospira interro- } \\
\text { gans, Borrelia spp. }\end{array}$ \\
\hline & 23 & $\begin{array}{l}\text { Збудники особливо небезпечних зоонозних інфекцій: чума, бруцельоз, сибірка, } \\
\text { туляремія. Історичний аспект поширення та купування епідемічних спалахів. } \\
\text { Біотероризм }\end{array}$ \\
\hline & 24 & $\begin{array}{l}\text { Актиноміцети, представники мікрофлори навколишнього середовища, патогенні } \\
\text { збудники захворювань людини. Методи дослідження. Патогенні найпростіші }\end{array}$ \\
\hline & 25 & $\begin{array}{l}\text { Внутрішньолікарняні інфекції: характеристика збудників, шляхи запобігання } \\
\text { та боротьби. Мікрофлора навколишнього середовища та методи її дослідження. } \\
\text { Екологічна мікробіологія. Мікробіом людини }\end{array}$ \\
\hline
\end{tabular}

розвивається і потребує фахівців біологів зі знаннями про морфологічні, функціональні, біохімічні та біологічні властивості патогенних й умовно-патогенних мікроорганізмів, вірусів та закономірності їх взаємодії з макроорганізмом, з популяцією людини й зовнішнім середовищем; патогенетичних основ формування імунної відповіді організму людини на дію інфекційних та неінфекційних подразників.

Клінічна мікробіологія, вірусологія та імунологія розвивається та поповнюється новою інфор- мацією про нові структури інфекційної патології, пов'язаною зі зростанням кількості збудників інфекцій, збільшенням частоти персистентних форм інфекційного процесу, розширенням спектра умовно-патогенних мікроорганізмів із множинною стійкістю до протимікробних засобів, використанням нових методів дослідження матеріалу та ідентифікації мікроорганізмів [6]. Для здобуття навичок відтворення інфекційного захворювання, приготування антигенів-діагностикумів, імунних сироваток для серологічних реакцій. А також зі зміною кількості 
годин у навчальному плані для здобувачів зі спеціальності 091 «Біологія» в робочій програмі були внесені зміни, які необхідні для опанування дисципліни за виділеної кількості годин та ознайомлення з сучасними науковими досягненнями в цих галузях клінічної мікробіології, вірусології та імунології.

Основні зміни, які відбулися в робочій програмі для докторів філософії зі спеціальності 091«Біологія»:

1. Лекції: кількість годин скоротилася з 40 год до 10 год:

- для лекції з розділів «Спеціальна бактеріологія» та «Вірусологія» було виділено лише 4 год, на яких презентувалася інформація про збудників, що передаються двома шляхами:

- Лекція 4. Патогенні мікроорганізми, що передаються повітряно-краплинним шляхом: вірус грипу, віруси кору, епідемічного паротиту, краснухи, хантавіруси, Neisseria meningitidis, Mycobacterium spp., Corynebacterium diphtheriae, Bordetella pertussis.

- Лекція 5. Збудники ентеровірусних інфекцій: пікорнавіруси, ротавіруси, норуолк віруси. Збудники бактерійних інфекцій шлунково-кишкового тракту: Escherichia coli, Klebsiella pneumoniae, Enterobacter spp., Campylobacter jejuni, Helicobacter pylori, Vibrio cholerae, Shigella spp., та Salmonella spp.

2. Практичні заняття: кількість годин скоротилася з 120 год до 56 год:

- у розділі I «Загальна мікробіологія як основа для вивчення життєдіяльності представників царства прокаріотів» звернено увагу на використання молекулярно-генетичних методів у мікробіологічній практиці та методологію дослідження інфікованих лабораторних тварин у мікробіологічній практиці:

- Заняття практичне 7. Характеристика основних методів ідентифікації бактерій. Використання молекулярно-генетичних методів у мікробіологічній практиці.

- Заняття практичне 9. Поняття про експериментальну інфекцію. Методологія дослідження інфікованих лабораторних тварин у мікробіологічній практиці;

- у розділі II «Практична імунологія» розглянуто сучасні методи створення вакцин та в темі про використання імунологічних методів у діагностиці розглянуто особливості цих методів та їх практичне використання:

- Заняття практичне 12. Препарати для проведення активної та пасивної імунізації. Сучасні методи створення вакцин.
- Заняття практичне 13. Типи та роль імунологічних методів діагностики у диференціації патологічних станів організму;

- у розділі III «Прикладна мікробіологія та вірусологія» практичні заняття структуровані за здатністю збудників проникати в організм людини, зокрема збудники діарейних бактеріальних інфекцій, збудники ентеровірусних інфекцій та інші.

3. Самостійна робота: кількість годин скоротилася $з 200$ год до 114 год:

- у розділі I «Загальна мікробіологія як основа для вивчення життєдіяльності представників царства прокаріотів» винесено теми, які розкривають сучасні досягнення мікробіології в методах індикації бактерій, особливостей їх культивування і механізми резистентності бактерії та використання їх у біотехнологічних процесах;

- у розділі II «Практична імунологія» винесено теми механізми уникнення мікроорганізмів імунного захисту, методи оцінки імунного статусу організму, особливості імунної відповіді, спричиненої різними патогенами;

- у розділі III «Прикладна мікробіологія та вірусологія» винесено теми про перспективи використання діагностичних та лікувальних препаратів бактеріофагів у медицині, методи діагностики вірусних інфекцій, а також збудники вірусних та бактеріальних інфекцій, патогенних грибів та найпростіших.

Для підготовки в ТНМУ ім. І. Я. Горбачевського для студентів-аспірантів використовується навчальна платформа «Moodle», призначена для об’ єднання викладачів і аспірантів в одну надійну, безпечну та інтегровану систему для створення персоналізованого навчального середовища.

Проте важливим моментом у створенні робочої програми є направленість на спеціалізацію здобувача, та формувати тематику занять, які б відповідали найактуальнішим та перспективнішим напрямкам і зближували науково-дослідну діяльність з освітньо-навчальним процесом.

Висновки та перспективи подальших досліджень. Таким чином, зміни в робочій програмі «Мікробіологія, вірусологія і імунологія» для підготовки докторів філософії за спеціальністю 091 «Біологія» спрямовані на поєднання навчальної діяльності з науковим пошуком.

Перспективами подальших досліджень вбачаємо внесення змін змісту навчальної дисципліни з урахуванням думки здобувачів третього рівня вищої освіти, зовнішніх стейкхолдерів. 


\section{Список літератури}

1. Гордійчук С. В. Забезпечення якості підготовки магістрів та докторів філософії (PhD) з медсестринства в умовах реформування вищої медичної освіти / С. В. Гордійчук // Підготовка докторів філософії (PhD) в умовах реформування вищої освіти : матеріали Всеукр. наук.-практ. конф. (Запоріжжя, 5-6 жовтня 2017 р.). Запоріжжя : Запорізький національний університет, 2017. - C. 212-215.

2. Кліщ І. М. Досвід підготовки докторів філософії за освітньо-науковими програмами у державному вищому навчальному закладі «Тернопільський державний медичний університет імені І. Я. Горбачевського Міністерства охорони здоров’я України» / I. М. Кліщ, Н. Я. Потіха, О. С. Ковалик // Медична освіта. - 2018. № 2. - C. 121-124.

3. Мамотова Т. В. Зміст та особливості викладання дисципліни «Управління науковими проектами» за програмою підготовки докторів філософії «Публічне управління та адміністрування» / Т. В. Мамотова, Н. М. Рудік // Підготовка докторів філософії (PhD) в умовах реформування вищої освіти : матеріали Всеукр. наук.-практ. конф. (Запоріжжя, 5-6 жовтня 2017 р.). -
Запоріжжя : Запорізький національний університет, 2017. - С. 208-211.

4. Особливості підготовки докторів філософії за освітньо-науковими програмами у ДЗ «Дніпропетровська медична академія МО3 України» / Т. О. Перцева, В. Й. Мамчур, Н. М. Онул, В. В. Горбунцов // Підготовка докторів філософії (PhD) в умовах реформування вищої освіти : матеріали Всеукр. наук.-практ. конф. (Запоріжжя, 5-6 жовтня 2017 р.). - Запоріжжя : Запорізький національний університет, 2017. - С. 182-185.

5. Порядок підготовки здобувачів вищої освіти ступеня доктора філософії та доктора наук у вищих навчальних закладах (наукових установах), затверджений Постановою Кабінету Міністрів України від 23.03.2016 р. № 261 [Електронний ресурс]. - Режим доступу : http://zakon2.rada.gov.ua/laws/show/261-2016$\% \mathrm{D} 0 \% \mathrm{BF}$.

6. Структуризація та проблеми викладання клінічної мікробіології на етапі інтернатури / Г. К. Палій, В. П. Широбоков, С. А. Іванова, В. П. Ковальчук // Biomedical and biosocial anthropology. - 2016. - № 26. C. $187-188$.

\section{References}

1. Hordiychuk, S.V. (2017). Zabezpechennia iakosti pidhotovky mahistriv ta doktoriv filosofii (PhD) z medsestrynstva $\mathrm{v}$ umovakh reformuvannia vyshchoi medychnoi osvity [Ensuring the quality of training of masters and doctors of philosophy (PhD) in nursing in the context of reforming higher medical education]. Pidhotovka doktoriv filosofii (PhD) v umovakh reformuvannia vyshchoi osvity: materialy Vseukrainskoi naukovo-praktychnoi konferentsiiTraining of Doctors of Philosophy (PhD) in the context of higher education reform: materials of the All-Ukrainian scientific-practical conference. Zaporizhzhia: Zaporizkyy natsionalnyy universytet [in Ukrainian].

2. Klishch, I.M., Potikha, N.Ya., \& Kovalyk, O.S. (2018). Dosvid pidhotovky doktoriv filosofii za osvitno-naukovymy prohramamy u derzhavnomu vyshchomu navchalnomu zakladi «Ternopilskyy derzhavnyy medychnyy universytet imeni I.Ya. Horbachevskoho Ministerstva Okhorony Zdorovia Ukrainy» [The experience of doctors' of philosophypreparation for educational and scientific programs at the State Institution of Higher Education "I.Ya. Horbachevsky Ternopil State Medical University of Ministry of Health of Ukraine”]. Medychna osvita - Medical Education, 2, 121124 [in Ukrainian].

3. Mamotova, T.V., \& Rudik, N.M. (2017). Zmist ta osoblyvosti vykladannia dystsypliny «Upravlinnia ukovymy proektamy» za prohramoiu pidhotovky doktoriv filosofii «Publichne upravlinnia ta administruvannia» [Content

and features of teaching the discipline "Management of scientific projects" according to the training program of doctors of philosophy "Public administration and administration”]. Pidhotovka doktoriv filosofii (PhD) $v$ umovakh reformuvannia vyshchoi osvity: materialy Vseukrainskoi naukovo-praktychnoi konferentsii - Training of Doctors of Philosophy (PhD) in the context of higher education reform: materials of the All-Ukrainian scientificpractical conference. Zaporizhzhia: Zaporizkyy natsionalnyy universytet [in Ukrainian].

4. Pertseva, T.O., Mamchur, V.Y., Onul, N.M., \& Horbuntsov, V.V. (2017). Osoblyvosti pidhotovky doktoriv filosofii za osvitno-naukovymy prohramamy u DZ «Derzhavna medychna akademiia MOZ Ukrainy» [Peculiarities of training doctors of philosophy according to educational and scientific programs in the State Medical Academy of the Ministry of Health of Ukraine]. Pidhotovka doktoriv filosofii (PhD) v umovakh reformuvannia vyshchoi osvity: materialy Vseukrainskoi naukovo-praktychnoi konferentsii - Training of Doctors of Philosophy $(\mathrm{PhD})$ in the context of higher education reform: materials of the AllUkrainian scientific-practical conference. Zaporizhzhia: Zaporizkyy natsionalnyy universytet [in Ukrainian].

5. (2016). Poriadok pidhotovky zdobuvachiv vyshchoi osvity stupenia doktora filosofii ta doktora nauk u vyshchykh navchalnykh zakladakh (naukovykh ustanovakh) [The order of preparation of applicants for higher education for 
the degree of Doctor of Philosophy and Doctor of Science in higher educational institutions (scientific institutions)]. zakon2.rada.gov.ua Retrieved from: http://zakon2.rada. gov.ua/laws/show/261- 2016-\%D0\%BF.

6. Paliy, H.K., Shyrobokov, V.P., Ivanova, S.A., \& Kovalchuk, V.P. (2016). Strukturyzatsiia ta problemy vykladannia klinichnoi mikrobiolohii na etapi internatury [Restructuring and problems of teaching clinical microbiology during internship]. Biomedical and Biosocial Anthropology, 26, 187-188 [in Ukrainian].

Електронна адреса для листування: kravecnj@tdmu.edu.ua 